\title{
Molecular genetics of bacteriophages of lactic acid bacteria
}

\author{
EK Arendt, M van de Guchte, AG Coffey, C Daly, GF Fitzgerald
}

\author{
Department of Food Microbiology and National Food Biotechnology Centre, \\ University College, Cork, Ireland
}

\begin{abstract}
Summary - Bacteriophage infection of lactic acid bacteria starter cultures can result in serious disruption or even failure of fermentation processes. With the help of newly developed techniques, progress has been made in the molecular characterisation of phages of lactic acid bacteria (LAB) and also in the elucidation of the nature of their interaction with host cultures. A number of receptors involved in phage adsorption have been indentified and DNA penetration and injection, as well as the intracellular development of the $L A B$ phages have been investigated. The structural organisation of Lactobacillus and lactococcal phage genomes have also been determined and a number of phage genes has been cloned and sequenced. These include determinants for phage lysin and phage structural proteins. Specific loci, attachment sites (att), involved in the integration of temperate phage genomes, the cohesive ends (cos), involved in phage genome circularisation and the packaging sites (pac) of circularly permuted phages have been localised and in many cases characterised at a molecular level.
\end{abstract}

lactic acid bacteria / bacteriophages / molecular characterisation / lysogeny

Résumé - Génétique moléculaire des bactériophages des bactéries lactiques. Les infections des cultures starter de bactéries lactiques par des bactériophages peuvent provoquer de sérieuses perturbations ou même l'arrêt du processus de fermentation. Grâce aux techniques nouvellement développées, des progrès ont été faits dans la caractérisation moléculaire des phages des bactéries lactiques, ainsi que dans la compréhension de la nature de leur interaction avec les cultures hôtes. Plusieurs récepteurs impliqués dans l'adsorption des phages ont été identifiés et l'on a étudié la pénétration et linjection de l'ADN, ainsi que le développement intracellulaire des phages des bactéries lactiques. On a déterminé l'organisation structurale des génomes de phages de Lactobacillus et de Lactococcus, et de nombreux gènes phagiques ont été clonés et séquencés. Cela inclut des déterminants de la lysine et de protéines structurales phagiques. Des loci spécifiques, sites d'attachement (att), impliqués dans l'intégration des génomes des phages tempérés, les extrémités cohésives (cos), impliqués dans la circularisation des génomes phagiques et les sites d'empaquetage (pac) des phages à permutations circulaires, ont été localisés et, dans de nombreux cas, caractérisés au niveau moléculaire. 


\section{INTRODUCTION}

Bacteriophage infection is known as the major cause of the inhibition of LAB starter cultures used in food fermentations. This is particularly true in the dairy industry for the following reasons: the fermentation is carried out in a non sterile-medium (pasteurised milk); batch culture fermentations are conducted under increasingly stringent manufacturing schedules; the amount of specialized cultures available on the market is limited; and the continuous use of defined cultures provides an ever-present host for bacteriophage attack. Through the years, efforts have been made to identify the major species of bacteriophages of $L A B$, to elucidate the specific nature of their interactions with their hosts and to define their physiological and genetic traits as an aid to determining their molecular characteristics. The information obtained will provide novel approaches for the con- struction of phage resistant starter cultures and will assist in the identification of factors controlling phage gene expression.

\section{PHAGE ADSORPTION}

The first step in the interaction between a lytic phage and its host occurs when the phage particle adsorbs to the cell surface. Electron microscopic studies with lactococcal phages have shown that these either adsorb to their homologous hosts in small groups (5-30 phages) at evenly distributed spots or they adsorb uniformly over the cell surface (Budde-Niekiel and Teuber, 1987). Phage receptors are generally cell wall located; an overview of phage receptors identified to date is presented in table I. Recently, Valyasevi et al (1991) reported that the reversible binding to the cell wall polysaccharide is followed by an irreversible interaction with a cell membrane located protein.

Table I. Phage receptors of $L A B$.

Receptor

Phage

Reference

\section{Lactococcus}

Lipoprotein of the plasma membrane

$Ø \mathrm{~m} 13$

Oram, 1971

L-Rhamnose, D-galactosamine

$1 \mathrm{~b} 7$

Koegh and Pettingill,

D-glucosamine (cell-wall associated)

Rhamnose, extracellular

Økh 1983

polysaccharide

Carbohydrate component

P008, P127

Valysevi et al, 1990

of the peptidoglycan

\section{Lactobacillus}

Rhamnose (cell-wall), D-galactosamine

(cytoplasmic membrane)

$\mathrm{Pl}-1$

Yokokura, 1977

L-Rhamnosyl (peptidoglycan)

PL-1

Ishibashi et al, 1982 


\section{DNA PENETRATION AND INJECTION}

For Lactobacillus casei phage PL-1, it has been shown that $\mathrm{Ca}^{2+}$ and ATP were essential for penetration of the phage DNA (Watanabe and Takesue, 1972; Watanabe et al, 1979). Watanabe et al (1991) have examined injection of $L b$ casei phage PL-1 by electronmicroscopy and have demonstrated that the process was inhibited by chloramphenicol and erythromycin, both of which inhibit protein synthesis. Thus it is possible that protein synthesis is needed in the early stage of the phage infection and is necessary for complete DNA transfer and injection.

\section{INTRACELLULAR DEVELOPMENT OF LAB PHAGES}

The burst sizes and the latent periods of the $L A B$ phages are summarised in table II. Generally, the optimum temperature for phage replication is similar to that of the host strain. Phage multiplication can also be dependent on the nutritional status of the host and on electrolyte availability, both of which can be active in promoting phage replication and cell lysis (Keogh, 1980; Klaenhammer, 1984).
Very little is known about the intracellular development of $L A B$ phages at a molecular level. Hill et al (1991a) have reported that the DNA molecules of the cohesive ended phage 31 are synthesized in a concatameric form between 20-40 min after infection of $L$ lactis NCK203. Sixty min after infection, there was a decrease in the detectable amount of phage DNA, which was possibly due to packaging and release of the phage particles. Powell et al (1992) have analysed the replication of the broad host range prolate-headed phage $c 6 \mathrm{~A}$ and found that infection of $L$ lactis $\mathrm{C} 6$ caused inhibition of culture growth within $10 \mathrm{~min}$ and cell lysis after $25 \mathrm{~min}$. DNA synthesis was detected after $6-8 \mathrm{~min}$ and stayed constant until cell lysis. Using ${ }^{3} \mathrm{H}$ thymidine-labelled host DNA, it could be shown that degradation of the host DNA occurred after 4-6 min. The breakdown products were incorporated into the phage DNA. Molecular studies with the $L b$ case $i$ phage PI-1 showed that it used unmodified host RNA polymerase to transcribe its entire genome. Early genes were expressed within the first $20 \mathrm{~min}$, whereas the late genes were expressed after 40 min (Stetter et al, 1978).

Following the synthesis of the phage macromolecular components, the phage

Table II. Intracellular development of LAB phages.

\begin{tabular}{llll}
\hline Organism & $\begin{array}{l}\text { Latent } \\
\text { period }(\mathrm{min})\end{array}$ & $\begin{array}{l}\text { Burst } \\
\text { size }\end{array}$ & Reference \\
\hline $\begin{array}{l}\text { Lactococcus } \\
10-140\end{array}$ & $10-400$ & $\begin{array}{l}\text { Keogh, 1973 } \\
\text { Klaenhammer, 1984 }\end{array}$ \\
$\begin{array}{l}\text { Lactobacillus } \\
\begin{array}{l}\text { Leuconostoc } \\
\text { mesenteroides }\end{array}\end{array}$ & $40-75$ & $80-300$ & Sechaud et al, 1988 \\
Leuconostoc oenos & 60 & 41 & Neve and Teuber, 1991 \\
\hline
\end{tabular}


particles are assembled by a mechanism which has not yet been elucidated. At the end of the latent period the peptidoglycan layer of the host cell is lysed by phage encoded lysozyme like lysin. Lysins of LAB phages have been isolated and characterised in detail (see table III).

\section{CLASSIFICATION OF LAB PHAGES}

Much effort has been focussed on the development of a coherent classification system for LAB phages. These taxonomic studies are very important for the following reasons: they provide an insight into the relationship between phages; they may allow identification of the origin of the phages disturbing fermentation processes; they provide knowledge of the genetic characteristics of phages, which can then be useful in predicting the potential utility of phage resistance mechanisms. Taxonomic characterisations of phage are based on morphology, DNA homology, protein composition and serological analy- sis. Since it is beyond the scope of this article to review the characterisation and classification of LAB phages, the reader is directed to a number of comprehensive publications dealing with this topic (LahbibMansais et al, 1988; Neve et al, 1989; Jarvis et al, 1991; Boizet et al, 1992).

\section{BACTERIOPHAGE GENOME CHARACTERISATION}

All $L A B$ phages examined to date possess double-stranded DNA. The majority of these appear to have cohesive ends although a few phages show a circularly permuted structure with terminal redundancy. This is based on the following criteria : the presence of submolar fragments after restriction analysis; evidence for the presence of a pac site at which packaging of the phage genome is initiated; the absence of cohesive ends; and homology between the submolar fragment containing the terminal redundancy and the area of the genome close to the pac site. The $\mathrm{G}+\mathrm{C}$

Table III. Genes/elements cloned from LAB phages.

\begin{tabular}{|c|c|c|}
\hline Gene/Element & Phage & Reference \\
\hline \multicolumn{3}{|l|}{ Lactococcus } \\
\hline Lysin & ØvML3 & Shearman et al, 1989 \\
\hline Minor structural proteins & F4-1 & Kim and Batt, 1991a,b \\
\hline Major capsid protein & F4-1 & Kim and Batt, 1991a,b \\
\hline Undefined ORF & $\varnothing 7-9$ & Kim and Batt, 1991c \\
\hline Llal methylase & $\varnothing 50$ & Hill et al, 1991b \\
\hline BK5-T promoter inhibitor & BK5-T & Lakshmidevi et al, 1990 \\
\hline $\begin{array}{l}\text { Phage encoded resistance and } \\
\text { phage origin of replication }\end{array}$ & $\varnothing 50$ & Hill et al, 1990 \\
\hline \multicolumn{3}{|l|}{ Lactobacillus } \\
\hline Lysin & LL-H & Trautwetter et al, 1986 \\
\hline Phage structural proteins & LL-H & $\begin{array}{l}\text { Trautwetter et al, } 1986 \\
\text { Alatassova et al, } 1987\end{array}$ \\
\hline Lysin & mv1 & Boizet et al, 1990 \\
\hline Insertion sequence ISL1 & ØFSV & Shimizu-Kadota et al, 1985 \\
\hline
\end{tabular}


contents of the LAB phages are as follows : Lactococcus (37-39 \%); Lb plantarum $(37 \%)$ and $L b$ casei $(45-48 \%)$. The genome lengths of LAB phages are summarised in table IV. Genetic determinants which have been cloned from phages of $L A B$ are summarised in table III.

\section{LYSOGENIC PHAGES OF LACTIC ACID BACTERIA}

Lytic phages are of major concern in dairy fermentations, since they are primarily responsible for the disruption of fermentation processes. However, there is also significant interest in phages which can enter an alternative relationship with their host, the lysogenic cycle. In this case, the phage genome integrates into the chromosome after injection into the target cell, usually by recombination between 2 sites termed attP (phage attachment site) and attB (bacterial attachment site) on their respective genomes. Little information is available regarding the molecular or genetic basis for control and maintenance of the lysogenic relationship in $L A B$ hosts.

Table IV. Genome length of LAB phages.

Organism

Lactococcal phage

Small isometric

Large isometric

Prolate-headed

Lactobacillus phage

L delbrüeckii

Streptococcus thermophilus phage

Leuconostoc mesenteroides phage

Leuconostoc oenos phage
Genome length ( $k b)$

29-40

53-55

18-22

$34-41$

75

$33.8-44.2$

27.4

25.3
The study of lysogeny in LAB is very worthwhile for a number of reasons. Lysogenic hosts can serve as a reservoir of lytic phage in dairy plants. One classical example demonstrating this was presented by Shimizu-Kadota et al (1983), who showed that a phage which was derived from a lysogenic $L b$ casei host, was able to infect a $L b$ casei strain used in a yakult fermentation.

Lysogeny can also serve as a model system for the analysis of the regulation and control of phage gene expression. The information obtained from such a study could be used, for example, in the construction of integration vectors. Chopin et al (1989) were able to generate a chromosomal integration vector harboring a fragment of lactococcal prophage DNA, which was homologous to a resident prophage in the host chromosome. Integration was achieved by homologous recombination. Temperate phages are also capable of mediating transduction which can be exploited to transfer plasmid- and chromosomallyencoded traits and which may also prove useful in developing chromosomal maps for various members of the $L A B$ (Fitzgerald and Gasson, 1988; Davidson et al, 1990). Transduction of lactose-fermentation ability and proteolytic activity has already been reported (McKay and Baldwin, 1974; Gasson, 1983; Fitzgerald and Gasson, 1988).

\section{CHARACTERISATION OF TEMPERATE PHAGES AT THE MOLECULAR LEVEL}

Lakshmidevi et al (1988) have characterised the temperate $L$ lactis subsp cremoris phage BK5-T in detail. The unit genome size of this phage is $37.6 \mathrm{~kb}$, and it was shown to be circularly permuted with terminal redundancy and therefore DNA packaging is carried out by a headfull mechanism, giving rise to considerable variation 
in genome size (39.7-46 kb). Its lysogenic host is $L$ lactis subsp cremoris BK5 but the phage is also capable of propagating lytically on $L$ lactis subsp cremoris $\mathrm{H} 2$. When phage BK5-T was grown on this lytic host, it lost its ability to lysogenize its lysogenic host, a feature which was linked to a deletion of $0.6-2.5 \mathrm{~kb}$ in a specific region of the genome, at a location separate from the attP site. Lakshmidevi et al (1990) also isolated 5 promoters from phage BK5-T and they could also identify a region (621 bp) on the phage genome which was responsible for the inactivation of 3 of these.

The temperate lactococcal phage Tuc2009 isolated from Lactococccus lactis subsp cremoris UC509 by induction with mitomycin $C$ has been analysed in some detail. The phage has a small isometrichead $(52 \mathrm{~nm})$, possesses a non-contractile tail $(152 \mathrm{~nm})$ and a base plate $(16 \mathrm{~nm}$ across). Electronmicroscopic examination of Lactococccus lactis subsp cremoris UC526 host cells mixed with phage Tuc2009 revealed that the phage particles attached evenly over the cell surface. When the structural proteins of the phage were analysed by SDS-PAGE 2 major proteins with a molecular weight of 30 and $21.5 \mathrm{kDa}$ were identified. The first 15 and 8 amino acids, respectively, were identified by $\mathrm{N}$-terminal sequencing (Arendt, unpublished results). Restriction analysis showed that phage Tuc2009 has a genome size of $\approx 40 \mathrm{~kb}$. No evidence could be obtained for the presence of cohesive sites (cos). More-over, the presence of the submolar fragments in restriction enzyme digests of the phage DNA suggested that packaging occurs though a headfull mechanism yielding circularly permuted genomes. The site at which packaging starts (pac), and the attachment site (attP), have been localised to particular restriction fragments. Based on DNA-RNA and DNADNA hybridization studies, early and late gene expression functions could be attributed to specific regions of the phage genome. Phage-specific DNA could be detected 40 min after infection and there was a consistent increase up to $80 \mathrm{~min}$, and thereafter the concentration of detectable DNA decreased presumably due to packaging. While low levels of transcription products were detected $28 \mathrm{~min}$ after infection of the host, there was not a significant increase in the level of RNA until $48 \mathrm{~min}$. Using various restriction fragments spanning the entire Tuc2009 genome to probe the RNA samples, it was possible to identify early and late functions on the phage restriction map (Fitzgerald, unpublished results).

\section{REFERENCES}

Alatossova T, Forsman P, Karvonen P, Vasala A (1987) Molecular biology of Lactobacillus lactis bacteriophage LL-H. FEMS Microbiol Rev 46, 41

Arendt EK, Neve H, Hammes WP (1990) Characterization of phage isolates from a phagecarrying culture of Leuconostoc oenos $58 \mathrm{~N}$. Appl Microbiol Biotechnol 34, 220--224

Boizet B, Lahbib-Mansais $\mathrm{Y}$, Dupont L, Ritzenthaler P, Mata M (1990) Cloning, expression and nucleotide sequence of an endolysin gene of a Lactobacillus buigaricus bacteriophage. FEMS Microbiol Rev 87, 60

Boizet B, Mata M, Mignot O, Ritzenthaler P, Sozzi T (1992) Taxonomic characterization of Leuconostoc mesenteroides and Leuconostoc oenos bacteriophages. FEMS Microbiol Lett 90, 211-216

Budde-Niekiel A, Teuber M (1987) Electron microscopy of the adsorption of bacteriophages to lactic acid streptococci. Milchwissenschaft $42,551-554$

Chopin M-C, Chopin A, Rouault A, Galleron N (1989) Insertion and amplification of foreign genes in the Lactococcus lactis subsp lactis chromosome. Appl Environ Microbiol 55, 1769-1774 
Davidson BE, Powell IB, Hillier AJ (1990) Temperate bacteriophages and lysogeny in lactic acid bacteria. FEMS Microbiol Rev 87 . 79-90

Fitzgerald GF, Gasson MJ (1988) In vivo gene transfer systems and transposons. Biochimie 70, 489-502

Gasson MJ (1983) Genetic transfer systems in lactic acid bacteria. Antonie van Leeuwenhoek 49, 275-282

Hill C, Miller LA, Klaenhammer TR (1990) Cloning, expression, and sequence determination of bacteriophage fragment encoding bacteriophage resistance in Lactococcus lactis. J Bacteriol 172, 6419-6426

Hill C, Miller LA, Klaenhammer TR (1991a) The bacteriophage resistance plasmid pTR2030 forms high-molecular weight multimers in lactococci. Plasmid 25, 105-112

Hill C, Miller LA, Klaenhammer TR (1991b) In vivo genetic exchange of a functional domain from a type II A methylase between lactococcal plasmid pTR2030 and a virulent bacteriophage. J Bacteriol 173, 4363-4370

Ishibashi K, Takesue S, Watanabe K, Oishi K (1982) Use of lectins to characterise the receptor sites for bacteriophage PL-1 of Lactobacillus casei. J Gen Microbiol 128, 2251 2259

Jarvis AW, Fitzgerald GF, Mata M, Mercenier A, Neve $H$, Powell IB, Ronda C, Saxelin M, Teuber $M$ (1991) Species and type phages of lactococcal bacteriophages. Intervirology 32 , 2-9

Keogh BP (1973) Adsorption, latent period and burst size of phages of some strains of lactic streptococci. J Dairy Res 40, 303-309

Keogh BP (1980) Appraisal of media and methods for assay of bacteriophages of lactic streptococci. Appl Environ Microbiol 40, 798802

Keogh BP, Pettingill G (1983) Adsorption of bacteriophage $1 \mathrm{~b} 7$ on Streptococcus cremoris EB7. Appl Environ Microbiol 45, 1946-1948

Kim JH, Batt CA (1991a) Molecular characterization of Lactococcus lactis bacteriophage F4-1. Food Microbio/ 8, 15-26

Kim JH, Batt CA (1991b) Nucleotide sequence and deletion analysis of a gene coding for a structural protein of Lactococcus lactis bacteriophage F4-1. Food Microbio/ 8, 27-36
Kim JH, Batt CA (1991c) Identification of a nucleotide sequence conserved in Lactococcus lactis bacteriophages. Gene 98, 95-100

Klaenhammer TR (1984) Interaction of bacteriophages with lactic streptococci. Adv Appl Microbiol 30, 1-29

Lahbib-Mansais $\mathrm{Y}$, Mata $\mathrm{M}$, Ritzenthaler $\mathrm{P}$ (1988) Molecular taxanomy of Lactobacillus phages. Biochimie 70, 429-435

Lakshmidevi G, Davidson BE, Hillier AJ (1988) Circular permutation of the genome of a temperate bacteriophage from Streptococccus cremoris BK5. Appl Environ Microbiol 54, 1039-1045

Lakshmidevi G, Davidson BE, Hillier AJ (1990) Molecular characterization of promoters of the Lactococcus lactis subsp cremoris temperate bacteriophage BK5-T and identification of a phage gene implicated in the regulation of promotor activity. Appl Environ Microbiol 56, 934-942

McKay LL, Baldwin KA (1974) Simultaneous loss of proteinase and lactose-utilizing enzyme activities in Streptococcus lactis and reversal loss by transduction. Appl Environ Microbiol $47,68-74$

Neve H, Teuber M (1991) Basic microbiology and molecular biology of bacteriophages of lactic acid bacteria in dairies. Bull Int Dairy Fed 263, 3-15

Neve H, Krusch U, Teuber M (1989) Classification of virulent bacteriophages of Streptococcus salivarius subsp thermophilus isolated from yoghurt and Swiss-type cheese. Appl Microbiol Biotechnol 30, 624-629

Oram JD (1971) Isolation and properties of a phage receptor substance from the plasma membrane of Streptococccus lactis ML3. J Gen Virol 13, 59-71

Powell IB, Tullock DL, Hillier AJ, Davidson BE (1992) Phage DNA synthesis and host DNA degradation in the life cycle of Lactococcus lactis bacteriophage c6A. J Gen Microbiol, in press

Schäfer A, Geis A, Neve H, Teuber M (1991) Bacteriophage receptors of Lactococccus lactis subsp diacetylactis $\mathrm{F} 7 / 2$ and Lactococcus lactis subsp cremoris Wg2-1. FEMS Microbiol Lett 78, 69-74

Sechaud L, Cluzel PJ, Rousseau M, Muller M-C, Accolas JP (1988) Bacteriophages of lactobacilli. Biochimie 70, 1011-1018 
Shearman C, Underwood H, Jury K, Gasson M (1989) Cloning and DNA sequence analysis of Lactococcus bacteriophage lysin gene. Mol Gen Genet 218, 214-221

Shimizu-Kadota M, Sakurai T, Tsuchida N (1983) Prophage origin of a virulent phage appearing on fermentations of Lactobacillus casei S-1. Appl Environ Microbiol 45, 669-674

Shimizu-Kadota M, Kiwaki M, Hirokawa H, Tsuchida N (1985) ISL1: a new transposable element in Lactobacillus casei. Mol Gen Genet 200, 214-221

Stetter KO, Priess H, Delius H (1978) Lactobacillus casei phage PL-1: molecular properties and first transcription studies in vivo and in vitro. Virology 87, 1-12

Trautwetter A, Ritzenthaler P, Alatossava $T$, Mata-Gilsinger M (1986) Physical and genetic characterization of the genome of Lactobacillus lactis bacteriophage LL-H. J Virol 59, $551-555$

Valyasevi R, Sandine WE, Geller BL (1990) The bacteriophage kh receptor of Lactococcus lactis subsp cremoris $\mathrm{KH}$ is the rhamnose of the extracellular wall polysaccharide. Appl Environ Microbiol 56, 1882-1889

Valyasevi R, Sandine WE, Geller BL (1991) A membrane protein is required for bacteriophage c2 infection of Lactococcus lactis subsp lactis C2. J Bacteriol 173, 6095-6100

Watanabe K, Takesue S (1972) The requirement for calcium in infection with Lactobacillus phages. J Gen Virol 17, 19-30

Watanabe K, Takesue S, Ishibashi K (1979) Adenosine triphosphate content in Lactobacillus casei and the blender-resistant phagecell complex-forming ability of cells on infection with PL-1 phage. J Gen Virol 42, 27-36

Watanabe K, Shirabe M, Nakashima Y, Kakita Y (1991) The possible involvement of protein synthesis in the injection of PL-1 phage genome into its host Lactobacillus casei. J Gen Microbiol 137, 2601-2603

Yokokura T (1977) Phage receptor material in Lactobacillus casei. J Gen Microbiol 100, 139-145 